\title{
Infection of West African Dwarf Rams With Trypanosoma Brucei Brucei and Trypanosoma Congolense Significantly Alter Serum Electrolytes, Redox Balance, Sperm Parameters, And Gonadal Morphology
}

Davinson Chuka Anyogu ( $\nabla$ davinson.anyogu@unn.edu.ng)

University of Nigeria, Nsukka https://orcid.org/0000-0003-2205-5400

Shodeinde Vincent O. Shoyinka

University of Nigeria Faculty of Veterinary Medicine

John Ikechukwu Ihedioha

University of Nigeria Faculty of Veterinary Medicine

\section{Research Article}

Keywords: Serum electrolytes, sperm parameters, Trypanosoma brucei brucei, Trypanosoma congolense, trypanotolerance, West African dwarf ram

Posted Date: November 12th, 2021

DOI: https://doi.org/10.21203/rs.3.rs-1017484/v1

License: (c) (i) This work is licensed under a Creative Commons Attribution 4.0 International License. Read Full License

Version of Record: A version of this preprint was published at Veterinary Research Communications on April 7th, 2022. See the published version at https://doi.org/10.1007/s11259-022-09921-8. 


\section{Abstract}

Trypanotolerance of the West African dwarf (WAD) breeds may not rule out significant pathophysiological changes that may affect productivity. In this study, the effects of infection of WAD rams with Trypanosoma brucei brucei (Tbb) and Trypanosoma congolense (Tc) on their serum levels of electrolytes [calcium, phosphorus, sodium, potassium]; oxidative stress markers [superoxide dismutase (SOD), malondialdehyde (MDA)]; and sperm parameters [sperm count, motility, vitality, and morphology] were investigated. Fifteen WAD rams, assigned to 3 groups ( $A, B$ \& $C$ ) of 5 rams each, were used for the study. Group A rams were infected with Tbb, while Group B rams were infected with Tc, both intraperitoneally, at the dose of $10^{6}$ trypanosomes/animal. Group $\mathrm{C}$ rams served as the uninfected control. The infections were monitored for 70 days. Serum calcium levels were significantly $(p<0.05)$ lower in Tbb and Tc infected rams compared to the control throughout the study. Serum sodium was significantly $(p<0.05)$ higher in the Tb infected rams compared to the Tc infected and control rams on days 14 and $28 \mathrm{PI}$. Serum SOD activity decreased while MDA levels increased in both infected groups of rams. Tbb infected rams were azoospermic, while Tc infected rams had lower sperm motility, vitality and concentration and higher number of abnormal sperm cells compared to the control. Necrotic and inflammatory lesions occurred in the testis and epididymis of both infected rams. These results suggest that in spite of trypanotolerance, trypanosome infections in the WAD rams significantly impact on health and reproduction.

\section{Introduction}

African animal trypanosomosis (AAT) is a vector-borne parasitic disease of serious economic importance to livestock production in sub-Saharan Africa, where the disease is endemic (Mulenga et al. 2020). It is caused by extracellular protozoa (trypanosomes), which are cyclically transmitted by several species of tsetse fly (Glossina spp.) (Serranito et al. 2021). The tsetse distribution area, or tsetse fly "belt," covers 39 African countries, whose economic development is thus significantly impacted (Alsan 2015). The effects of the disease in livestock are mitigated by chemotherapeutic intervention, which is the most effective and widely applied method for the control of AAT in sub-Saharan Africa (Giordani et al. 2016). Other trypanosomosis control methods involving the use of trypanotolerant livestock and direct tsetse control are sparingly utilized in Africa owing to their expensive and laborious nature (Obi et al. 2019).

Routinely, little importance is attached to trypanosomosis in small ruminants compared to cattle (Griffin 1978). Most available data on the disease in small ruminants are sourced from abattoir reports (Kalejaiye et al. 1995; Nawathe et al. 1995; Dadah et al. 1997). On the other hand, it has been suggested that great economic losses occur in small ruminants due to trypanosome infections (Griffin 1978; Griffin and Allonby 1979; Kalu and Edeghere 1985). Also, these animals have been incriminated as sources/reservoirs of infection to other animals and man (Mahmaud and Elmalik 1977; Scott et al. 1983). This neglect may be due to the misplaced emphasis on trypanotolerance. It was estimated that approximately $32 \%$ of sheep and $47 \%$ of goats in West and Central Africa are trypanotolerant and this is so because the West African dwarf (WAD) breeds are predominant in these regions (Agyemang 2005; Geerts et al. 2009). Trypanotolerance is defined as a multigenic trait that confers on some breeds of cattle, sheep and goats the ability to survive, reproduce and remain productive under trypanosomosis risk without the need for the use of chemicals to control the vector 
or drugs to control the parasite, while susceptible breeds die without treatments (Murray et al. 1984; d'leteren et al. 1998; Geerts et al. 2009). It had been reported that phenotypically, trypanotolerant livestock are able to control parasitaemia and anaemia and are less affected by weight loss during infection (Hanotte et al. 2003; Berthier et al. 2016). In spite of trypanotolerance, however, pathological changes that may significantly impact on productivity may occur in trypanosome infected WAD breeds.

Calcium, phosphorus, sodium and potassium are electrolytes with diverse biological functions and which are essential for optimal growth, health and reproduction in mammals (Yasothai 2014; Escalera-Valente et al. 2021). These electrolytes participate in the formation of bones and teeth, muscle contraction, permeability of cell membranes, blood clotting, enzymatic reactions, secretion of hormones, metabolism of lipids, carbohydrates and proteins, genetic transmission of nucleic acids, maintenance of normal osmotic pressure, and neural transmission (Devlin 1992; McDowell 1992; Shaker and Deftos 2000). As regards reproductive function, while extracellular sodium, $\mathrm{Na}(+)$, suppresses hyper-activation of sperm motility via $\mathrm{Na}(+)-\mathrm{Ca}$ (2+) exchanger (Takei and Fujinoki 2016), calcium is necessary for spermatogenesis, sperm motility, capacitation, acrosome reaction and fertilization (Li et al. 2016; Beigi Harchegani et al. 2019).

The fact that imbalances in these mineral elements coupled with oxidative stress, which also affects sperm morphology and physiology, may impact negatively on optimal health and productivity in mammals makes it pertinent to evaluate them in trypanosome-infected WAD rams. Such study may unveil "silent" but significant impacts of the disease in the WAD rams in regions where surveillance, vector control and chemotherapeutic interventions are overlooked while trypanotolerance is emphasized. Moreover, in susceptible animals, trypanosomes have been reported to cause testicular degeneration and inflammation, subnormal sperm count and structural damage to spermatozoa (Wada et al. 2016; Amin et al. 2020). If similar reproductive lesions occur in the trypanotolerant WAD rams, it would imply that trypanotolerance of the WAD sheep may be overrated. The objective of this study was, therefore, to evaluate the effects of $T$. brucei brucei and $T$. congolense infections on some serum electrolytes, oxidative stress markers, sperm parameters, serum testosterone levels, and gonadal morphology in WAD rams.

\section{Materials And Methods}

\section{Trypanosomes species/strain used}

The trypanosome parasites used were the Federer strains of T. brucei brucei and T. congolense (Savannah subgroup), which were sourced from the Nigerian Institute for Trypanosomiasis Research (NITR), Kaduna State, Nigeria and maintained in rats via passages.

\section{Animals}

Fifteen West African dwarf rams were used for the study. They were procured from local breeders in Nsukka Nigeria, and allowed to acclimatize for 3 weeks, during which period they were dewormed. All the rams were screened for trypanosomes and/or other haemoparasites, by buffy coat examination. They were placed on fresh forage and drinking water ad libitum. They were further randomly assigned to three groups $(A, B \& C)$ of five rams each. Group A rams were infected with $T$. brucei brucei, while Group B rams were infected with $T$. 
congolense, both intraperitoneally, at the dose of $10^{6}$ trypanosomes/animal. Group $\mathrm{C}$ rams served as the uninfected control.

\section{Estimation of parasitaemia}

Parasitaemia was checked daily, beginning from day 2 post-infection of groups $A$ and $B$. Once the infection was established, the levels of parasitaemia in the infected groups were determined weekly by wet mount and scored by rapid matching method (Paris et al. 1982; Herbert and Lumsden 1976).

\section{Serum sample collection and analyses}

Blood samples were collected before infection (day 0 ) and on days $14,28,42,56 \& 70$ post infection (PI). The blood samples collected $(4 \mathrm{ml})$ were dispensed into clean labelled plain test tubes and allowed 45 minutes to clot. Sera used for analyses were obtained by centrifuging the clotted blood in the test tubes at 3000 revolutions per minute (rpm) for 10 minutes. The serum samples were split into two aliquots and refrigerated. One aliquot was used for the assay of calcium, phosphorus, sodium, potassium, superoxide dismutase (SOD) and malondialdehyde (MDA), using commercially available test kits and a Diatek Blood Chemistry Analyzer (Diatek Instruments Co. Ltd., Wuxi, China) following manufacturers' instructions. The other aliquot was used to assay for serum testosterone concentration using sheep-specific testosterone test kit (MBS701270) (Mybiosource Inc., California, USA).

Specifically, serum sodium was determined by the magnesium-uranyl acetate method (Scott et al. 2008), using a sodium test kit (Teco Diagnostics, Anaheim California, USA). The serum potassium was determined by the direct turbidimetric spectrophotometric method (Hillman and Beyer 1967; Scott et al. 2008), using a potassium test kit (Teco Diagnostics, Anaheim, California, USA). Serum calcium levels were determined by the ortho- cresolphthalein direct method (Connerty and Briggs 1966; Endres and Rude 2008), while the level of phosphorus in serum was evaluated based on the Fiske-SubbaRow method (Fiske and SubbaRow 1925; Goodwin 1970; Endres and Rude 2008), using Quimica Clinica Applicada (QCA) Calcium and inorganic Phosphorus test kits (QCA, S. A. Spain), respectively. Serum superoxide dismutase (SOD) activity was evaluated by hydroxylamine method (Weydert and Cullen 2010), while serum malondialdehyde levels was measured by the modified thiobarbituric acid method (Plaser and Cushman 1966; Draper and Hadley 1990), using the Elabscience SOD and Malondialdehyde Assay Kits (Elabscience Biotechnology Co. Ltd., South Africa), respectively. All the analyses were completed within 24 hours of sample collection.

\section{Epididymal sperm evaluation: motility, morphology, vitality and concentration}

Three rams from each group were castrated on day $70 \mathrm{PI}$ under lignocaine anaesthesia. Both testes and epididymis were removed from each ram. Sperm motility was determined using the sperm diffusion method (Seed et al. 1996). Briefly, the epididymis was dissected from the testis. The cauda epididymis was sectioned from the vas deferens and the end of the tubule segment was immersed in a drop of pre-warmed phosphate

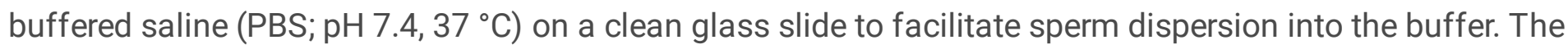
sperm cells were allowed to diffuse into the medium for 2 min. The tissue was removed, and the sperm cells were incubated for 5 minutes until adequately dispersed for analysis. Sperm motility (\%) was evaluated by examining the sample at x100 magnification using a phase-contrast microscope (Motic B3; Motic, Carlsbad, 
CA, USA) equipped with a stage slide warmer set at $37^{\circ} \mathrm{C}$ (TCS-100; Amscope, Ivrine, CA, USA). A total of 200 sperm cells were counted and the number of motile sperm cells recorded as percentage epididymal sperm motility.

Sperm vitality was determined after staining with eosin-nigrosin vital stain (Seed et al. 1996). Briefly, equal volume of caudal epididymal sperm suspension and eosin-nigrosin stain were mixed for 30 seconds and a thin smear made on a microscope slide and air-dried. Live sperm (unstained head) and dead sperm (redstained head) were identified using light microscopy (Motic B3; Motic, Carlsbad, CA, USA) at x1000 magnification under oil immersion. A total of 200 sperm cells were counted and the number of live sperm cells recorded as percentage vitality of the sample. All micrographs were captured using Moticam 2.0 image system (Motic, Carlsbad, CA, USA).

For sperm morphology, a wet mount of caudal epididymal sperm suspension was evaluated for sperm morphology and structural abnormalities at x1000 magnification using phase-contrast microscopy (Motic B3; Motic, Carlsbad, CA, USA). Sperm morphology was also determined using eosin-nigrosin staining method. A total of 200 sperm cells were counted and the number of abnormal sperm cells was recorded. This was expressed in percentage as epididymal total sperm abnormalities (TSA) (Seed et al. 1996).

To determine the sperm concentration, the cauda epididymal tissue was thoroughly minced and homogenized in $2 \mathrm{ml}$ of PBS ( $\mathrm{pH}$ 7.4). A 1:200 dilution of the homogenate was made in sperm dilution fluid containing formalin and gentian violet stain followed by counting of sperm cells using a haemocytometer (Weber, England). Total sperm count was expressed as number of spermatozoa/g epididymal tissue (Seed et al. 1996).

\section{Histopathology}

The testes were fixed in Bouin's fixative for 8 hours before transferring them to $70 \%$ alcohol. The epididymides were fixed in $10 \%$ neutral-buffered formalin for 48 hours. Both tissues were routinely processed and sectioned at $5 \mu \mathrm{m}$ thickness and stained with haematoxylin and eosin (H\&E).

\section{Statistical analysis}

The data were subjected to one way analysis of variance (ANOVA) using SPSS version 21. Parasitaemia scores were analysed by Student's $t$-test. The variant means were separated post hoc using the least significant difference method. Probability, $p<0.05$ was considered statistically significant.

\section{Results}

\section{Parasitaemia}

All the infected rams became parasitaemic between days 5 and $6 \mathrm{PI}$ and remained parasitaemic till the end of the study. Group A rams were significantly $(p<0.05)$ more parasitaemic than Group B rams on days 14,35 and $56 \mathrm{PI}$ (Figure 1).

\section{Serum minerals and electrolytes}


The mean serum calcium concentration of the infected rams were significantly $(p<0.05)$ lower than that of the uninfected control throughout the experiment, starting from day $14 \mathrm{PI}$ for the $T$. brucei brucei infected rams and day $28 \mathrm{PI}$ for $T$. congolense infected rams (Figure 2).

Serum phosphorus levels of the $T$. brucei brucei infected group was significantly $(p<0.05)$ lower than the control on days 14 and $28 \mathrm{PI}$. On days 42 and $56 \mathrm{Pl}$, the mean serum phosphorus level of the T. congolense infected group became significantly $(\mathrm{p}<0.05)$ higher than that of the $T$. brucei brucei infected group (Figure 3). Calcium/phosphorus ratio (Ca:P) was not affected in the T. brucei brucei infected rams (normal Ca:P = 12:1) but tilted towards hyperphosphataemia in $T$. congolense infected rams, from day $28 \mathrm{PI}(\mathrm{Ca}: \mathrm{P}=1: 1.2)$ to day $70 \mathrm{PI}(\mathrm{Ca}: \mathrm{P}=1: 1.5)$.

Serum sodium levels of Group A ( $T$. brucei brucei) rams was significantly $(\mathrm{p}<0.05)$ higher than that of Group $\mathrm{B}$ (T. congolense) and C (Control) on days 14 and $28 \mathrm{PI}$. Beyond day $28 \mathrm{PI}$, there were no significant variations in serum sodium concentrations across the groups (Figure 4). Potassium concentration in serum did not also vary significantly $(p>0.05)$ across the groups throughout the period of the experiment.

\section{Oxidative stress markers}

The mean serum superoxide dismutase (SOD) activity of the $T$. brucei brucei infected group was significantly $(p<0.05)$ lower than those of both the T. congolense infected group and the uninfected control on days 14 , 28 and $42 \mathrm{PI}$. However, by days 56 and $70 \mathrm{PI}$, it was significantly $(p<0.05)$ lower than only that of the control group. On the other hand, the mean serum SOD activity of the T. congolense infected group was significantly $(p<0.05)$ lower than that of the control from day $28 \mathrm{PI}$ to the termination of the experiment (Figure 5$)$.

The mean serum malondialdehyde (MDA) levels of the T. brucei brucei infected group was significantly ( $p<$ 0.05 ) higher than that of the control group by days 42 and $70 \mathrm{PI}$. Similarly, the mean serum MDA levels of the T. congolense infected group was significantly $(p<0.05)$ higher than the control by days 14 and $42 \mathrm{PI}$ and also significantly $(p<0.05)$ higher than that of Group A by days 14 and $28 \mathrm{PI}$ (Figure 6$)$.

\section{Sperm parameters: concentration, motility, vitality, and morphology}

No spermatozoon was found in the epididymal fluid of the T. brucei brucei infected rams (Group A). Sperm cells were present in the epididymides of Groups $B$ and $C$ rams. The mean serum epididymal sperm count of T. congolense infected rams (Group B) was significantly $(p<0.05)$ lower than that of the control (Group $C)$. The mean percentage sperm motility and vitality of the Group B rams were significantly $(p<0.05)$ lower than those of the control, while the mean percentage abnormality of spermatozoa of Group B rams were significantly $(p<0.05)$ higher than that of the control group (Table 1$)$.

Stained smear of the epididymal fluid of Group A rams did not reveal any sperm cells, only necrotic debris was observed. Motile trypanosomes ( $T$. congolense) were found in the epididymal semen of Group B rams (Figure 7A). The sperm morphological abnormalities observed in Group B rams were headless sperm cells, dead sperm cells, coil-tailed spermatozoa, short-tailed spermatozoa, and cytoplasmic droplets (Figure 7B). Group B had fewer and mainly abnormal sperms cells (Figure 7B), while Group C was a mixture of normal and abnormal sperm cells (Figure 7C). 


\section{Serum testosterone concentration}

The mean serum testosterone levels did not significantly vary across the groups from day 14 to day $56 \mathrm{Pl}$, although that of Group B dropped steadily from day 28 to day $42 \mathrm{PI}$ compared to that of Group A and the control. However, by day $70 \mathrm{Pl}$, the mean serum testosterone concentrations of the infected groups ( $\mathrm{A}$ and $\mathrm{B}$ ) were significantly $(p<0.05)$ lower than the control (Figure 8$)$.

\section{Histopathology}

The testicular tissues of the Group A rams infected with T. brucei brucei showed severe degeneration and necrosis of the germ cells of the seminiferous tubules and mild infiltration of mononuclear cells in the interstices (Figure 9A). Group B rams infected with T. congolense also showed severe testicular degeneration and subcapsular oedema with severely distended interstices due to infiltration of mononuclear cells (Figure 9B). The uninfected rams (Group C) showed normal germinal cells of the seminiferous tubules and normal interstices (Figure 9C).

The epididymis of Group A rams showed severe necrosis and desquamation of the tubular epithelial cells and severe infiltration of mononuclear inflammatory cells into the ductular walls and interstices (Figure 10A). That of Group B rams had similar lesions but the tubular cells were rather vacuolated and the connective tissues were severely thickened due to more severe infiltration of mononuclear inflammatory cells (Figure 10B). The epididymis of the control group appeared normal with clumps of spermatozoa in the tubules (Figure 10C).

\section{Discussion}

The finding in the present study that mean serum calcium for the infected groups were significantly $(p<0.05)$ lower than the values for the control throughout the study, starting from day $14 \mathrm{PI}$ in $T$. brucei brucei infected group and day $28 \mathrm{PI}$ in T. congolense infected group, agrees with the reports of Allam et al. (2011) in pigs in which persistent decline in serum calcium was observed and also with the reports of Da Silva et al. (2011) on rabbits, in which decline in serum calcium was observed on day $35 \mathrm{PI}$. It is possible that the trypanosomes utilized extracellular calcium for their intracellular metabolism. Calcium is said to be important for flagella function and life cycle of trypanosomes (Docampo and Huang 2015) and for microtubule assembly, release of variant surface glycoprotein and activation of adenylate cyclase (Voorheis and Martin 1981; Bowles and Voorheis 1982; Dolan et al. 1986). The thought that trypanosome infections may have caused disruptions in the functions of the parathyroid glands involved in minute-to-minute fine regulation of blood calcium as was shared in another report of a study in pigs experimentally infected with T. brucei, in which persistent decline in serum calcium level was observed (Allam et al. 2011) seems likely.

In the later stages of the infections (i.e from day $42 \mathrm{PI}$ ) the mean values for serum phosphorus of the $T$. congolense infected group were significantly $(\mathrm{p}<0.05)$ higher than the values for $T$. brucei brucei infected group, which in turn was significantly $(p<0.05)$ lower than those of the control group on days 14 and $28 \mathrm{PI}$. A previous study (Da Silva et al. 2011) reported a reduction in serum phosphorus level on day $35 \mathrm{Pl}$, which compared favourably with the phosphorus level for $T$. brucei brucei infected group in this study, but does not 
agree with the values for $T$. congolense infected group, in which normal Ca:P ratio (2:1) tilted towards hyperphosphatemia (1:1.5). This implies that calcium/phosphorus homeostasis regulated by the parathyroid gland may be differently altered in T. congolense and T. brucei brucei infections in the WAD rams.

Mean serum sodium levels of the $T$. brucei brucei infected rams were significantly $(p<0.05)$ higher than the values for the T. congolense infected rams on days 14 and $28 \mathrm{PI}$. There were no significant $(p>0.05)$ differences in the mean serum potassium values for the infected groups and control throughout the study. These results differ from a previous study in rabbits (Da Silva et al. 2011) in which decreased serum levels of both sodium and potassium were reported. The lack of agreement with the present study may be due to animal species differences or possibly a more effective regulation of $\mathrm{Na} / \mathrm{k}$ homeostasis in the infected WAD rams.

Oxidative stress in the infected rams was characterized by significantly lower SOD activity in both infected groups throughout the study period, and significantly higher MDA levels at the early phase of the infection in $T$. congolense infected rams and at the later phase in T. brucei brucei infected rams. The findings of this study, especially as regards $T$. congolense infected group agree with other studies in camels and cattle, which are trypano-susceptible, in which increased MDA activities and decreased SOD activities were reported following T. evansi infection (Saleh et al. 2009; Mishra et al. 2017).

Necrotic lesions in the seminiferous and epididymal tubules were more severe in the T. brucei brucei infected rams. Inflammatory lesions, however, predominated in the testicular and epididymal stromal tissues in the $T$. congolense infected rams. These results agree with previous reports of trypanosome-induced testicular and epididymal degeneration and inflammation in Yankassa rams (Okubanjo et al. 2014). These lesions in the testis and epididymis in addition to the lowered serum testosterone levels may have also contributed to azoospermia reported for $T$. brucei brucei infected rams and the sperm abnormalities observed in the $T$. congolense infected group, which agree with previous reports of aspermatogenesis in T. brucei brucei in sheep (Ikede and Losos 1972), gazelle (Mbaya 2007) and sperm abnormalities in cattle infected with $T$. congolense (Sekoni et al. 2004). It should be noted also that testosterone is required for normal spermatogenesis (Smith and Walker 2014) and the inflammatory lesions in the testicular stroma, which were more severe in the $T$. congolense infected rams than in the T. brucei brucei infected rams, may have correspondingly affected serum testosterone levels. Furthermore, the finding of motile trypanosomes in the epididymal semen of the $T$. congolense infected group suggests that this parasite may also be tissue invasive and not strictly haematic (Abebe et al. 1993). Its presence in the semen may have equally caused severe stress to sperm cells, hence, contributing to the reported sperm morphological and physiological alterations.

\section{Conclusions}

The findings of this study have revealed that in spite of trypanotolerance, severe pathological changes, capable of affecting fertility, occurred in WAD rams infected separately with $T$. brucei brucei and $T$. congolense. The patho-mechanism involved direct stress to sperm cells due to invasion of the cauda epididymis by $T$. congolense, degeneration, necrosis and inflammation of the testis and epididymis; and infection-induced redox imbalance and serum electrolyte perturbations, especially calcium. Therefore, 
trypanosome infections in the trypanotolerant WAD rams significantly affect health and reproduction even in the absence of mortality or clear signs of morbidity.

\section{Declarations}

Acknowledgements: The authors are grateful to the Nigerian Institute for Trypanosomiasis Research (NITR) for donating the trypanosomes used for the study; we thank Mr. I.O. Agbakwuru for assisting in tissue processing, and Foundation for Education and Research in Health (FERH), Nsukka, Nigeria for bench space and other technical assistance provided.

Authors' contributions: Conceptualization: [Davinson C Anyogu, Shodeinde VO Shoyinka, John I Ihedioha]; Methodology: [Davinson C Anyogu, John I Ihedioha]; Formal analysis and investigation: [Davinson C Anyogu, John I Ihedioha]; Writing-original draft preparation: [Davinson C Anyogu]; Writing-review and editing: [Davinson C Anyogu, John I Ihedioha, Shodeinde VO Shoyinka]; Resources: [Davinson C Anyogu, John I Ihedioha, Shodeinde VO Shoyinka]; Supervision: [Shodeinde VO Shoyinka, John I Ihedioha].

Ethics approval: Approval was obtained from the Institutional Animal Care and Use Committee (IACUC) of the Faculty of Veterinary Medicine, University of Nigeria, Nsukka (Approval Reference Number: FVM-UNN-IACUC2020-0345). All efforts were made to minimise the discomfort of the animals during sampling.

Consent to participate: All authors participated voluntarily in the research.

Consent for publication: All authors read and approved the final manuscript.

Conflicts of interest/Competing interest: The authors declare no conflict of interest.

\section{Funding}

This study was supported by Institutional Based Research (IBR) grant from Tertiary Education Trust Fund (TETFund/DESS/UNI/NSUKKA/2018/RP/VOL.1).

\section{References}

1. Abebe G, Eley RM, ole-MoiYoi OK (1993) Reduced responsiveness of the hypothalamic-pituitary-adrenal axis in Boran (Bos inducus) cattle infected with Trypanosoma congolense. Acta Endocrinol (Copenh) 129(1):75-80. https://doi.org/10.1530/acta.0.1290075

2. Agyemang K (2005) Trypanotolerant livestock in the context of trypanosomiasis intervention strategies. PAAT Techn Sci Ser 7:1-66

3. Allam L, Ogwu D, Agbede RIS, Sackey AKB (2011) Haematological and serum biochemical changes in gilts experimentally infected with Trypanosoma brucei. Vet Arh 81(5):597-609

4. Alsan M (2015) The effect of the tsetse fly on African development. Am Economic Rev 105:382-410. https://doi.org/10.1257/aer.20130604 
5. Amin YA, Noseer EA, Fouad SS, Ali RA, Mahmoud H (2020) Changes of reproductive indices of the testis due to Trypanosoma evansi infection in dromedary bulls (Camelus dromedarius): Semen picture, hormonal profile, histopathology, oxidative parameters, and hematobiochemical profile. J Adv Vet Anim Res 7(3):537-545. https://doi.org/10.5455/javar.2020.g451

6. Beigi Harchegani A, Irandoost A, Mirnamniha M, Rahmani H, Tahmasbpour E, Shahriary A (2019) Possible Mechanisms for the Effects of Calcium Deficiency on Male Infertility. Int J Fertil Steril 12(4):267-272. https://doi.org/10.22074/ijfs.2019.5420

7. Berthier D, Brenière SF, Bras-Gonçalves R, Lemesre JL, Jamonneau V, Solano P et al (2016) Tolerance to trypanosomatids: A threat, or a key for disease elimination? Trends Parasitol 32:157-168. https://doi.org/10.1016/j.pt.2015.11.001

8. Bowles DJ, Voorheis HP (1982) Release of the surface coat from the plasma membrane of intact bloodstream forms of Trypanosoma brucei requires $\mathrm{Ca}^{2+}$. FEBS Lett 139: 17-21. https://doi.org/1016/0014-5793(82)80477-8

9. Connerty HV, Briggs AR (1966) Determination of serum calcium by means of ortho-cresolphthalein complexone. Am J Clin Pathol 45(3):290-296. https://doi.org/10.1093/ajcp/45.3.290

10. Da Silva AS, Costa MM, Moreira CM, Zenette RA, Thome GR, Otto MA, Flores EMM, Lopes STA, Monterio SG (2011) Experimental infection by Trypanosome evansi in rabbits: Levels of sodium, potassium, calcium and phosphorus in serum. Acta Sci Vet 39(2):959

11. Dadah AJ, Duhlinska-Popova DD, Daniel AD, Dede PM (1997) Trypanosomosis among sheep and goats at slaughter in Jos abattoir. Nigeria Rev élev méd vét pays trop (En ligne) 50:214-216

12. Devlin TM (1992) Text book of Biochemistry with Clinical Correlations. John Wiley \& Sons Inc., New York, pp 289-1185

13. d'leteren GD, Authié E, Wissocq N, Murray M (1998) Trypanotolerance, an option for sustainable livestock production in areas at risk from trypanosomosis. Rev Sci Tech 17(1):154-175. https://doi.org/10.20506/rst.17.1.1088

14. Docampo R, Huang G (2015) Calcium signalling in trypanosomatid parasites. Cell Calcium 57(3):194202. https://doi.org/10.1016/j.ceca.2014.10.015

15. Dolan MT, Reid CG, Voorheis HP (1986) Calcium ions initiate the selective development of the pellicular microtubules in bloodstream forms of Trypanosome brucei. J Cell Sci 80:123-140

16. Draper HH, Hadley M (1990) Malondialdehyde determination as an index of lipid peroxidation. Methods Enzymol 186:421-431. https://doi.org/10.1016/0076-6879(90)86135-i

17. Endres DB, Rude RK (2008) Measurement of calcium. In: Burtis CA, Ashwood ER, Bruns DE (eds) Tietz Fundamentals of Clinical Chemistry, 6th edn. Missouri, Saunders Elsevier, pp 715-717

18. Escalera-Valente F, Alonso ME, Lomillos JM, Gaudioso VR, Alonso ÁJ, González-Montaña JR (2021) Effect of Intense Exercise on Plasma Macrominerals and Trace Elements in Lidia Bulls. Vet Sci 8(6):97. https://doi.org/10.3390/vetsci8060097

19. Fiske $\mathrm{CH}$, SubbaRow $\mathrm{Y}$ (1925) The colorimetric determination of phosphorus. J Biol Chem 66:375-400

20. Geerts S, Osaer S, Goossens B, Faye D (2009) Trypanotolerance in small ruminants of sub-Saharan Africa. Trends Parasitol 25(3):132-138. https://doi.org/10.1016/j.pt.2008.12.004 
21. Giordani F, Morrison LJ, Rowan TG, De Koning HP, Barrett MP (2016) The animal trypanosomiases and their chemotherapy: a review. Parasitology 143:1862-1889.

https://doi.org/10.1017/S0031182016001268

22. Goodwin JF (1970) Quantification of serum inorganic phosphorus, phosphatase and urinary phosphate without preliminary treatment. Clin Chem 16(9):776-780

23. Griffin L (1978) African trypanosomiasis in sheep and goats: a review. Vet Bull 48:819-823

24. Griffin L, Allonby EW (1979) The economic effects of trypanosomiasis in sheep and goats in a range research station in Kenya. Trop Anim Health Prod 11:127-132. https://doi.org/10.1007/BF02237788

25. Hanotte O, Ronin Y, Agaba M, Nilsson P, Gelhaus A, Horstmann R et al (2003) Mapping of quantitative trait loci controlling trypanotolerance in a cross of tolerant West African N'Dama and susceptible East African Boran cattle. Proc Natl Acad Sci USA 100:7443-7448.

https://doi.org/10.1073/pnas.1232392100

26. Herbert WJ, Lumsden WHR (1976) Trypanosoma brucei: A rapid "matching" method for estimating the host's parasitaemia. Exp Parasitol 40:427-431. https://doi.org/10.1016/0014-4894(76)90110-7

27. Hillman G, Beyer G (1967) Turbidimetric determination of potassium in serum. J Klin Chem Klin Biochem 5:92-93

28. Ikede BO, Losos GJ (1972) Pathology of the disease in sheep produced experimentally by Trypanosoma brucei. Vet Pathol 9:278-289. https://doi.org/10.1177/030098587200900408

29. Kalejaiye JO, Ayanwale FO, Ocholi RA, Daniel AD (1995) The prevalence of trypanosome in sheep and goats at slaughter. Isr J Vet Med 56:57-59

30. Kalu AU, Edeghere HU (1985) Trypanosoma vivax in Nigerian goats. Economic effects of the infection. Niger J Anim Prod 12:45-50

31. Li X, Wang L, Li Y, Zhao N, Zhen L, Fu J, Yang Q (2016) Calcium regulates motility and protein phosphorylation by changing CAMP and ATP concentrations in boar sperm in vitro. Anim Reprod Sci 172:39-51. https://doi.org/10.1016/j.anireprosci.2016.07.001

32. Mahmaud MM, Elmalik KH (1977) Trypanosomiasis: goats as a possible reservoir of Trypanosoma congolense in the Republic of Sudan. Trop Anim Health Prod 9:167-170.

https://doi.org/10.1007/BF02236591

33. Mbaya AW (2007) Studies on trypanosomosis in captive red fronted gazelles (Gazella rufifrons) in Nigeria. PhD thesis, University of Maiduguri, Nigeria. pp.100-240

34. McDowell LR (1992) Minerals in Animal and Human Nutrition. Academic Press, San Diego, p 524

35. Mishra RR, Senapati SK, Sahoo SC, Das MR, Sahoo G, Patra RC (2017) Trypanosomiasis induced oxidative stress and hemato-biochemical alteration in cattle. J Entomol Zool Stud 5(6):721-727

36. Mulenga GM, Henning L, Chilongo K, Mubamba C, Namangala B, Gummow B (2020) Insights into the Control and Management of Human and Bovine African Trypanosomiasis in Zambia between 2009 and 2019-A Review. Trop Med Infect Dis 5(3):115. https://doi.org/10.3390/tropicalmed5030115

37. Murray M, Trail JCM, Davis CE, Black SJ (1984) Genetic Resistance to African Trypanosomiasis. J Infect Dis 149:311-319. https://doi.org/10.1093/infdis/149.3.311 
38. Nawathe DR, Strivastava GC, Basu AK, Kollere MA (1995) Trypaosomiasis in small ruminants in the arid zone, Nigeria. Bull Anim Health Prod Afr 43:293-294

39. Obi CF, Nzeakor TA, Okpala MI, Ezeh IO, Nwobi LG, Omeje MO, Ezeokonkwo RC (2019) Evaluation of antitrypanosomal activity of Pterocarpus santalinoides hydroethanol leaf extract in rats experimentally infected with Trypanosoma brucei. J Ethnopharmacol 243:112085.

https://doi.org/10.1016/j.jep.2019.112085

40. Okubanjo OO, Sekoni VO, Ajanusi OJ, Nok AJ, Adeyeye AA (2014) Testicular and epididymal pathology in Yankasa rams experimentally infected with Trypanosoma congolense. Asian Pac J Trop Dis 4(3):185189

41. Paris J, Murray M, McOdimba F (1982) A comparative evaluation of parasitological techniques currently available for the diagnosis of African trypanosomiasis in cattle. Acta Trop 39:307-316

42. Plaser ZA, Cushman LL (1966) Estimation of product of lipid peroxidation (malonyldialdehyde) in biochemical systems. Anal Biochem 16:359-364. https://doi.org/10.1016/0003-2697(66)90167-9

43. Saleh MA, Al-Salahy MB, Sanousi SA (2009) Oxidative stress in blood of camels (Camelus dromedaries) naturally infected with Trypanosoma evansi. Vet Parasitol 162:192-199.

https://doi.org/10.1016/j.vetpar.2009.03.035

44. Scott MC, Frezil JL, Toudic A, Godfrey DG (1983) A sheep as potential reservoir of human trypanosomiasis in the Republic of Congo. Trans R Soc Trop Med Hyg 77:397-401. https://doi.org/10.1016/0035-9203(83)90172-4

45. Scott MG, Legrys VA, Klutts JS (2008) Analytical methodology for the determination of sodium and potassium. In: Burtis CA, Ashwood ER, Bruns DE (eds) Tietz Fundamentals of Clinical Chemistry, 6th edn. Missouri, Saunders Elsevier, pp 433-435

46. Seed J, Chapin RE, Clegg ED, Dostal LA, Foote RH, Hurtt ME, Klinefelter GR, Makris SL, Perreault SD, Schrader S, Seyler D, Sprando R, Treinen KA, Veeramachaneni DN, Wise LD, ILSI Risk Science Institute Expert Working Group on Sperm Evaluation (1996) Methods for assessing sperm motility, morphology, and counts in the rat, rabbit, and dog: a consensus report. Reprod Toxicol 10(3):237-244. https://doi.org/10.1016/0890-6238(96)00028-7

47. Sekoni VO, Rekwot PI, Bawa EK (2004) The effects of trypanosomosis on sperm morphology in Zebu $x$ Friesian crossbred bulls. Trop Anim Health Prod 36(1):55-64.

https://doi.org/10.1023/b:trop.0000009528.91525.01

48. Serranito B, Taurisson-Mouret D, Harkat S, Laoun A, Ouchene-Khelifi NA, Pompanon F, Benjelloun B, Cecchi G, Thevenon S, Lenstra JA, Da Silva A (2021) Search for Selection Signatures Related to Trypanosomosis Tolerance in African Goats. Front Genet 12:715732. https://doi.org/10.3389/fgene.2021.715732

49. Shaker JL, Deftos L Calcium and Phosphate Homeostasis. [Updated 2018 Jan 19]. In: Feingold KR, Anawalt B, Boyce A, editors. Endotext [Internet]. South

Dartmouth(MA):MDText.com,Inc.;2000.Availablefrom:https://www.ncbi.nlm.nih.gov/books/NBK279023/

50. Smith LB, Walker WH (2014) The regulation of spermatogenesis by androgens. Semin Cell Dev Biol 30:2-13. https://doi.org/10.1016/j.semcdb.2014.02.012

Page $12 / 21$ 
51. Takei GL, Fujinoki M (2016) Regulation of hamster sperm hyperactivation by extracellular $\mathrm{Na}$. Reproduction 151(6):589-603. https://doi.org/10.1530/REP-15-0367

52. Voorheis HP, Martin BR (1981) Characteristics of the calcium-mediated mechanism activating adenylate cyclase in Trypanosoma brucei. Eur J Biochem 116:471-477. https://doi.org/10.1111/j.14321033.1981.tb05360.x

53. Wada YA, Oniye SJ, Rekwot PI, Okubanjo 00 (2016) Testicular pathology, gonadal and epididymal sperm reserves of Yankasa rams infected with experimental Trypanosoma brucei brucei and Trypanosoma evansi. Vet World 9(7):759-765. https://doi.org/10.14202/vetworld.2016.759-765

54. Weydert CJ, Cullen JJ (2010) Measurement of superoxide dismutase, catalase and glutathione peroxidase in cultured cells and tissues. Nat Protoc 5(1):51-66. https://doi.org/10.1038/nprot.2009.197

55. Yasothai R (2014) Importance of minerals on reproduction in dairy cattle. Int J Sci Environ Technol 3(6):2051-2057

\section{Tables}

Table 1: Epididymal sperm parameters of WAD rams infected with T. brucei brucei and T. congolense for 70 days (Mean \pm standard error)

$\begin{array}{lccc}\text { Sperm parameters } & \text { T. brucei brucei } & \text { T. congolense } & \text { Control } \\ \text { Count (/g epididymis) } & \text { NSS } & 0.63 \pm 0.35 \times 10^{6^{*}} & 19.60 \pm 1.97 \times 10^{6} \\ \text { Motility (\%) } & \text { N/A } & 12.00 \pm 2.08^{*} & 72.33 \pm 2.40 \\ \text { Vitality (\%) } & \text { N/A } & 31.00 \pm 1.76^{*} & 86.33 \pm 5.69 \\ \text { Abnormality (\%) } & \text { N/A } & 56.67 \pm 4.48^{\star} & 22.00 \pm 1.73\end{array}$

*Significant difference at probability, $p<0.05$. NSS: No spermatozoon seen. N/A: Not applicable

\section{Figures}




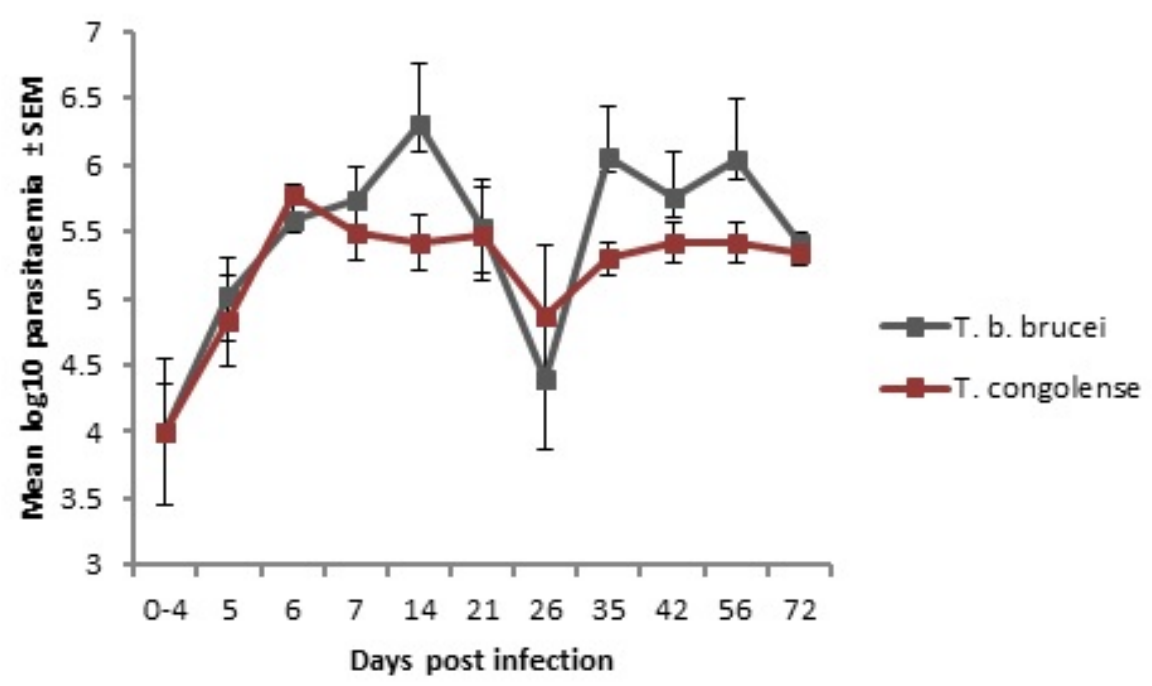

Figure 1

Mean weakly parasitaemia scores of West African dwarf rams infected with $\mathrm{T}$. brucie brucei and $\mathrm{T}$. congolense for 70 days.

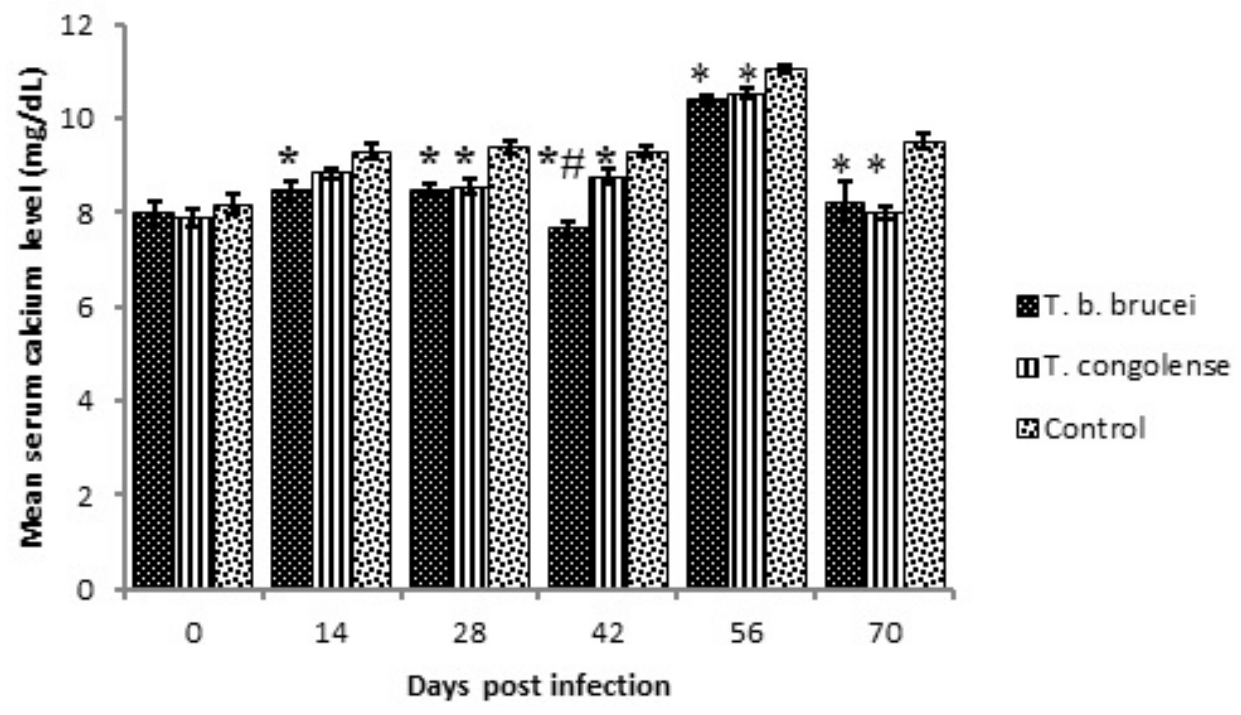

Figure 2

Mean serum calcium concentrations $(\mathrm{mg} / \mathrm{dL})$ of West African dwarf rams infected with $\mathrm{T}$. brucie brucei and T. congolense for 70 days. ${ }^{*} p<0.05$ vs. control. $\# p<0.05$ vs. T. congolense. 


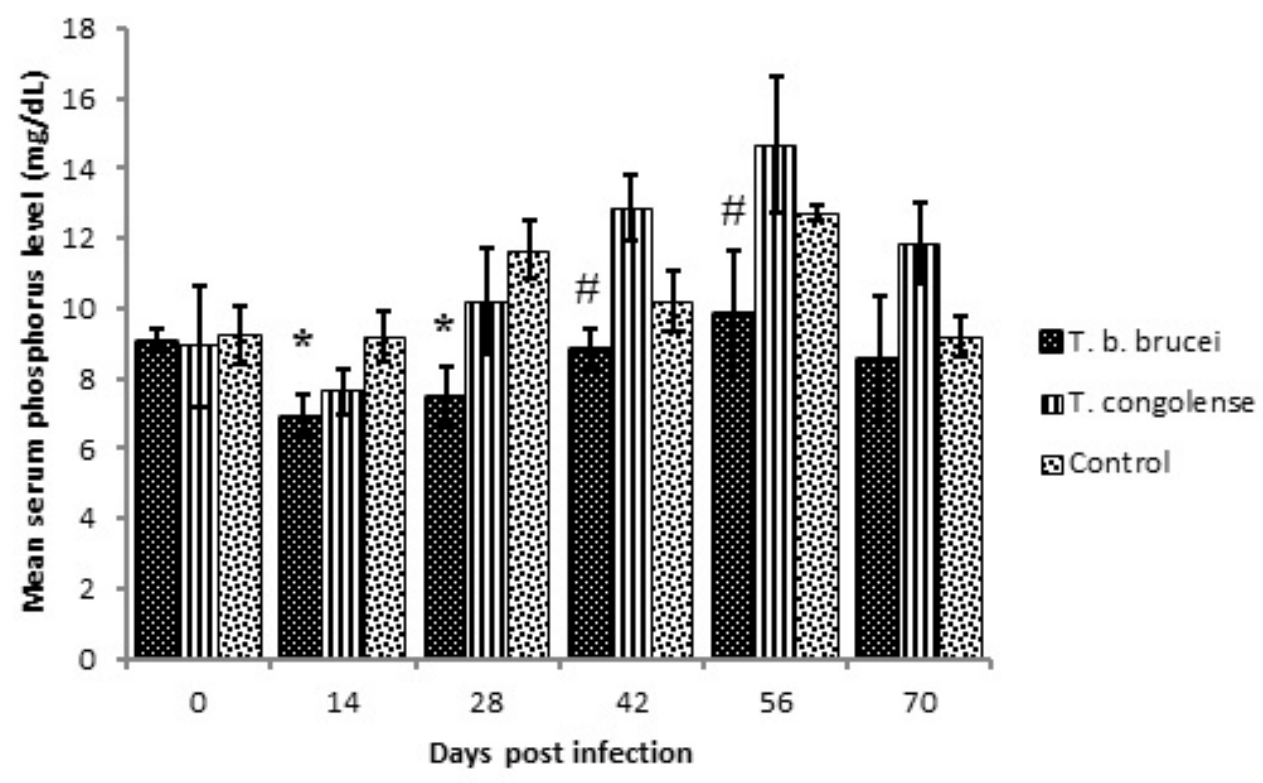

Figure 3

Mean serum phosphorus concentrations $(\mathrm{mg} / \mathrm{dL})$ of West African dwarf rams infected with $\mathrm{T}$. brucie brucei and T. congolense for 70 days. ${ }^{*} p<0.05$ vs. control. $\# p<0.05$ vs. T. congolense.

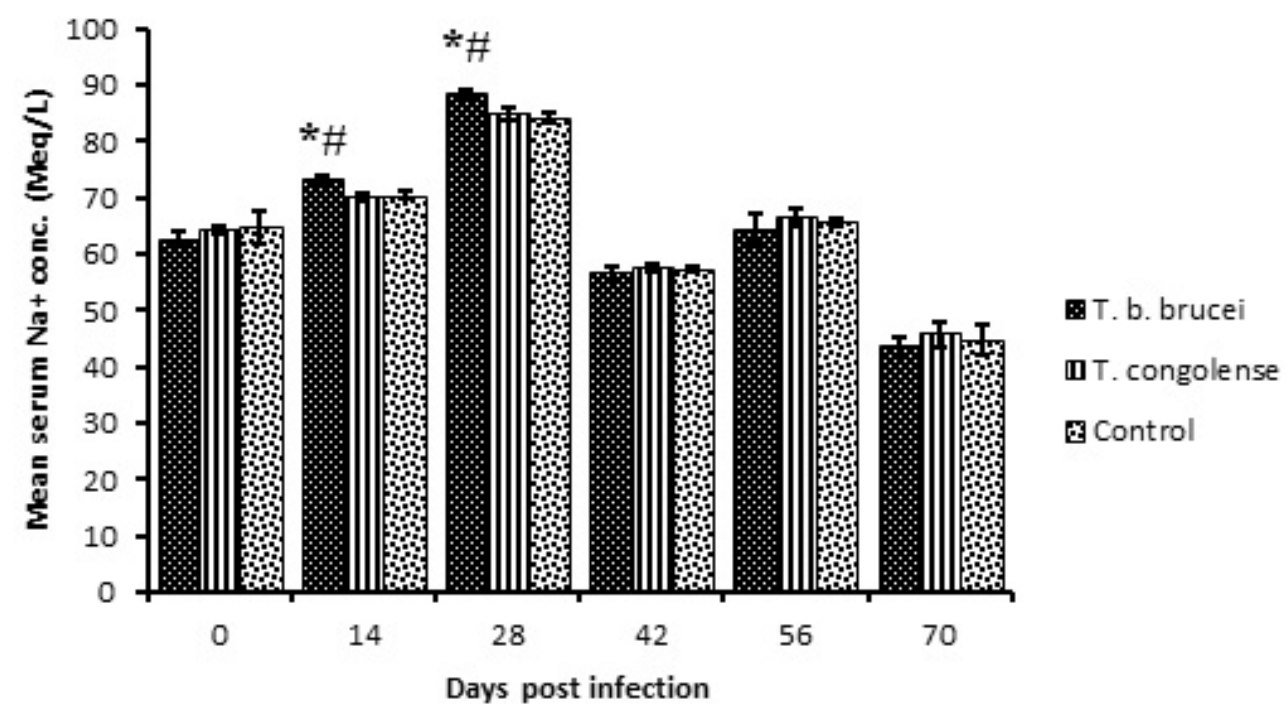

Figure 4

Mean serum sodium concentrations (Meq/L) of West African dwarf rams infected with $\mathrm{T}$. brucie brucei and T. congolense for 70 days. ${ }^{\star} p<0.05$ vs. control. $\# p<0.05$ vs. T. congolense. 


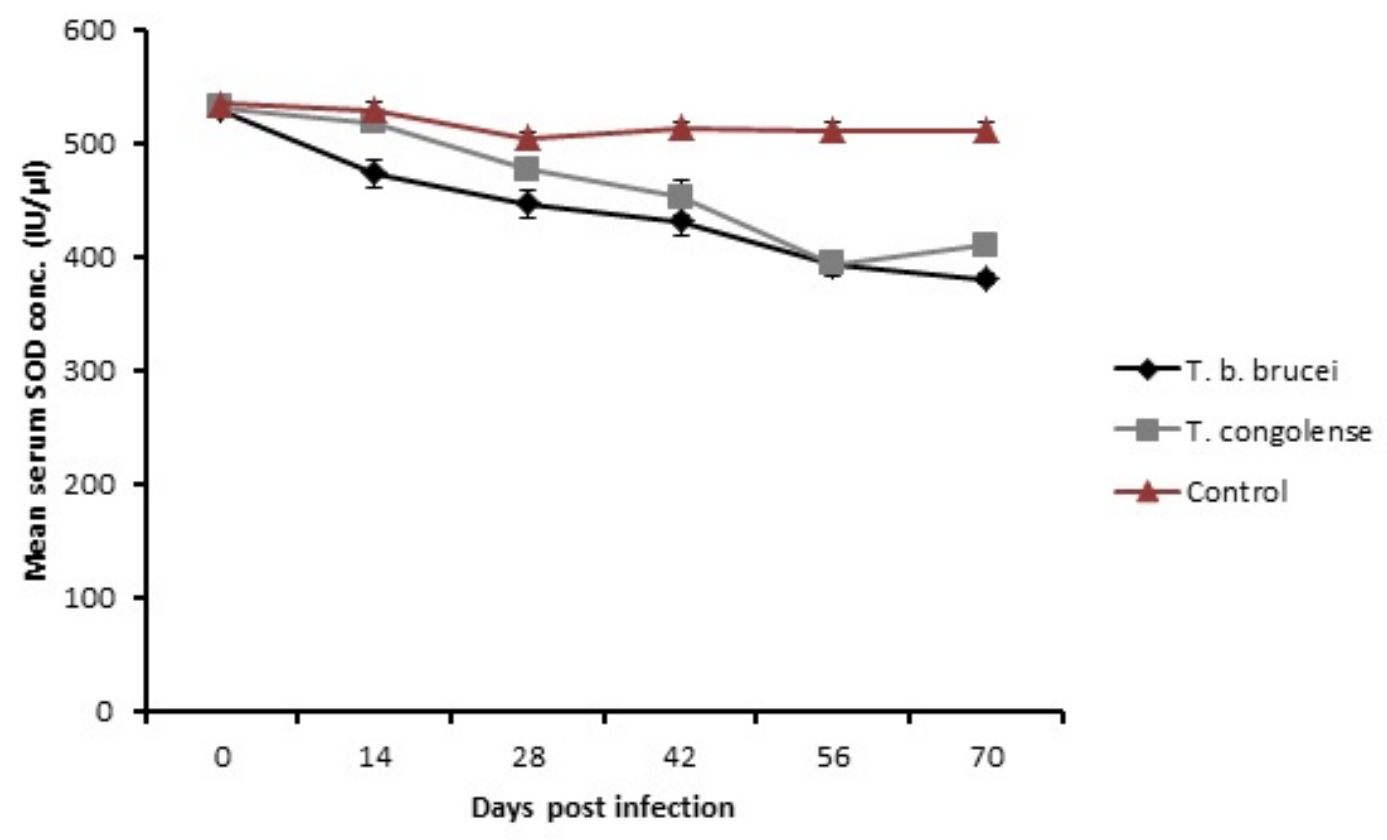

\section{Figure 5}

Mean serum superoxide dismutase activity $(\mathrm{IU} / \mu \mathrm{L})$ of West African dwarf rams infected with $\mathrm{T}$. brucie brucei and $\mathrm{T}$. congolense for 70 days.

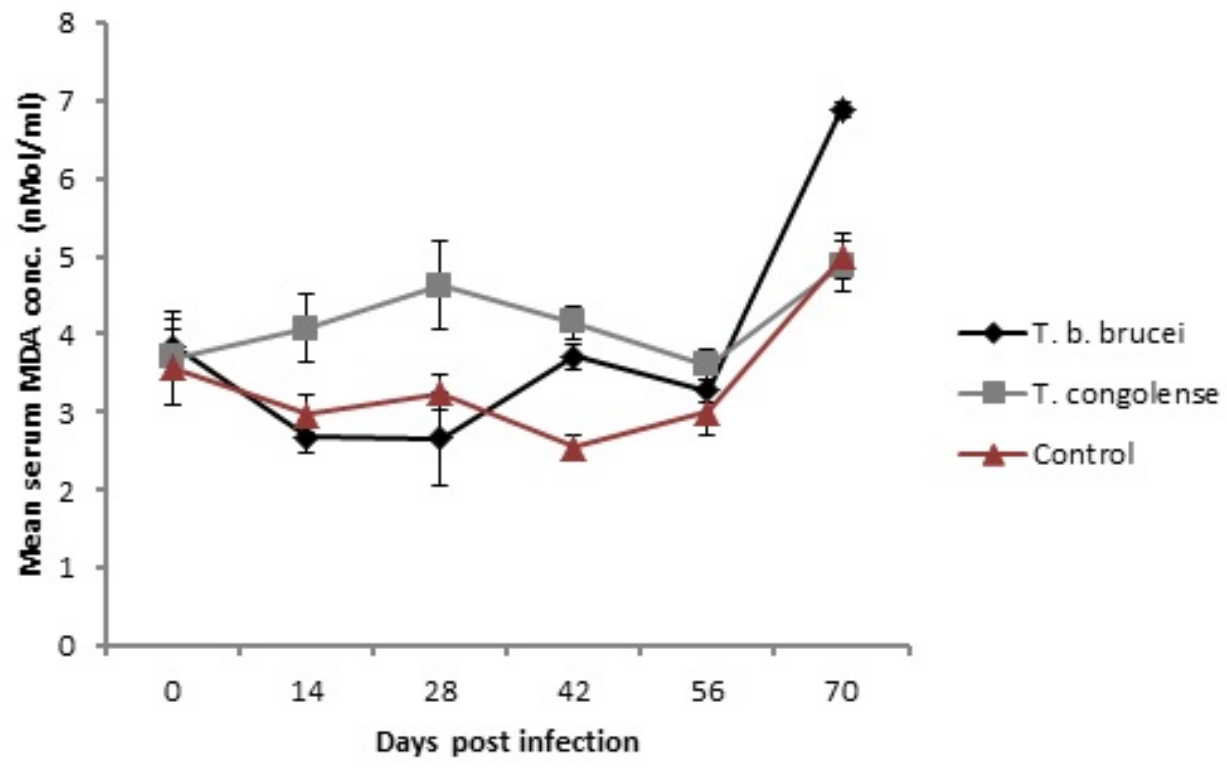

\section{Figure 6}

Mean serum malondialdehyde concentration $(\mathrm{nMol} / \mathrm{mL})$ of West African dwarf rams infected with $\mathrm{T}$. brucie brucei and T. congolense for 70 days. 

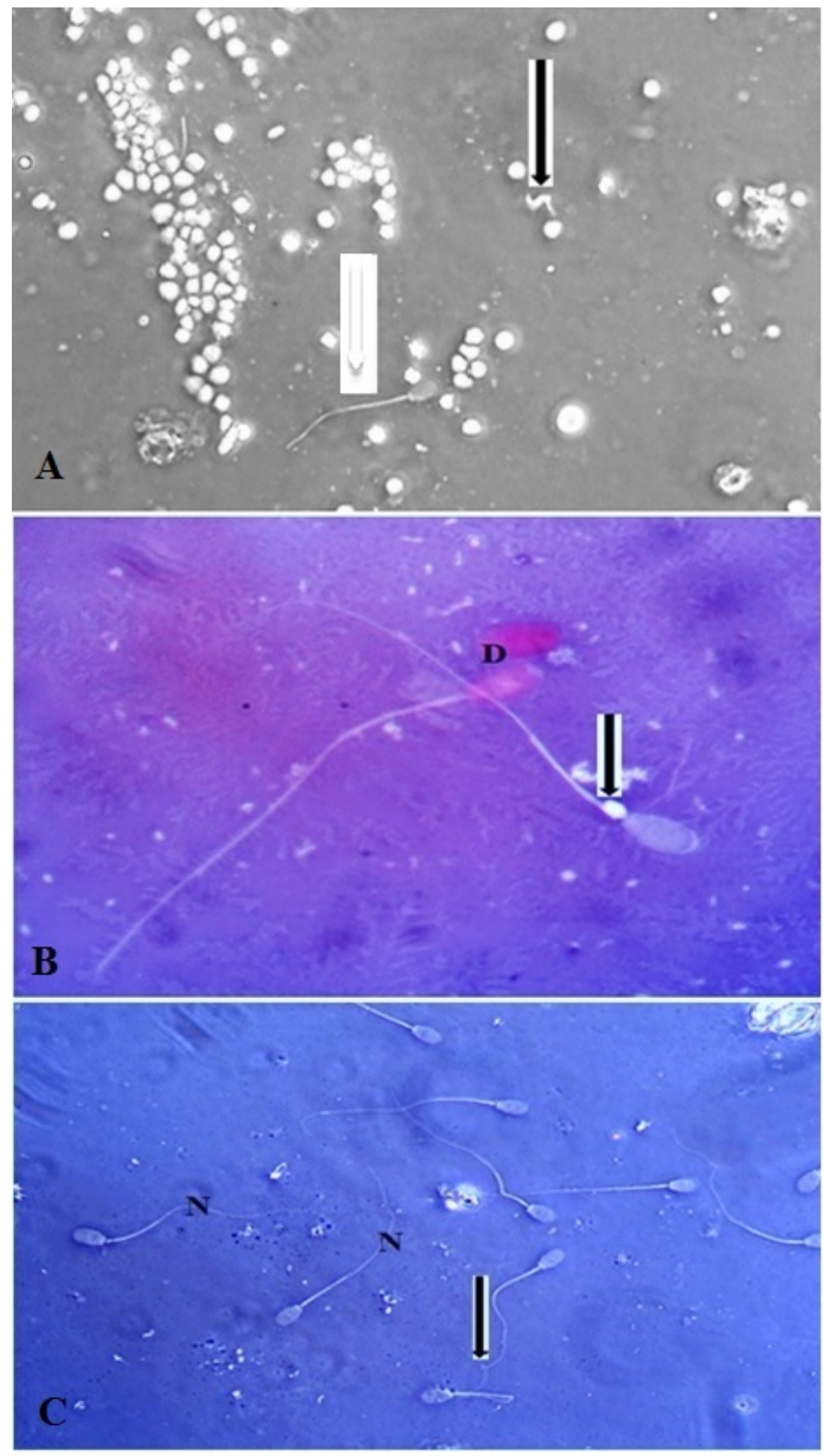

\section{Figure 7}

A: Epididymal semen droplet (diluted with normal saline) of T. congolense infected West African dwarf (WAD) ram showing trypanosome (black arrow) captured in motion, and short-tailed spermatozoon (white arrow) on day 70 PI. Phase contrast microscope (x400). B: Semen smear of T. congolense infected WAD ram showing dead sperm cells (D) and cytoplasmic droplet (arrow). C: Semen smear of the uninfected group showing both normal (N) and coil-tailed sperm cells (arrows). Eosin-negrosin vital stain, day $70 \mathrm{PI},(\mathrm{B}, \mathrm{x} 1000 ; \mathrm{C}, \mathrm{x400})$. 


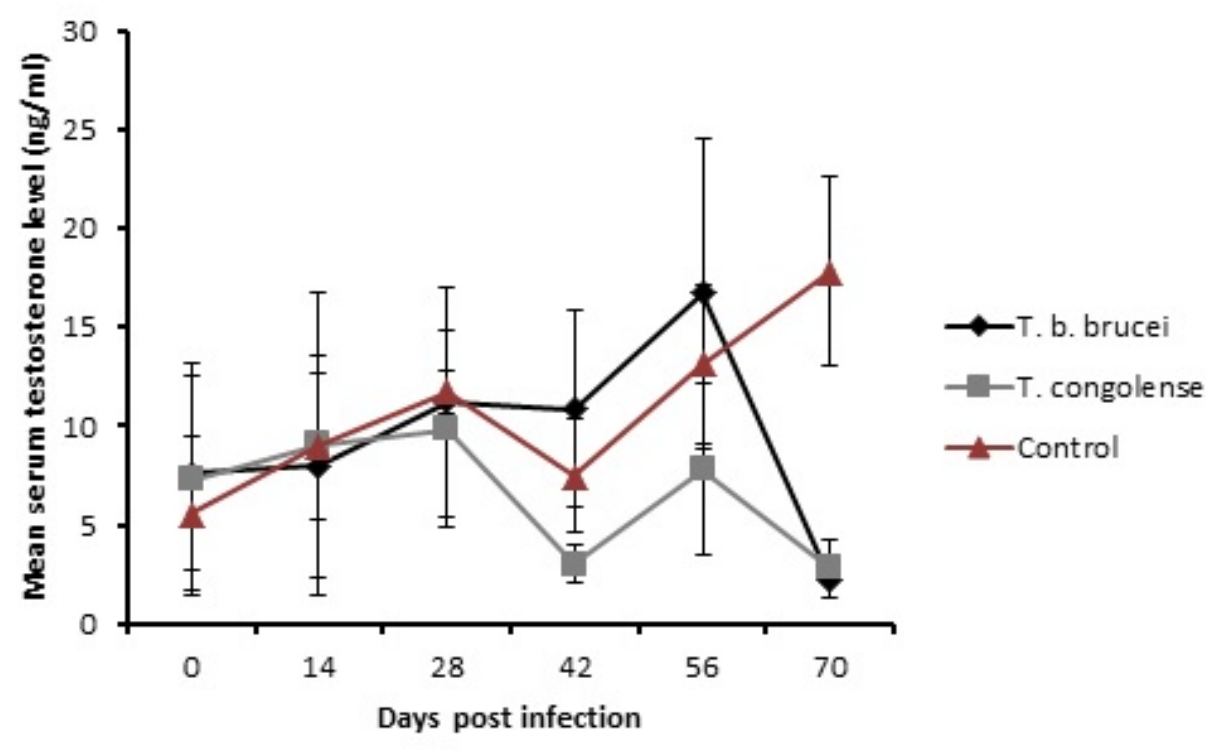

Figure 8

Mean serum testosterone concentration $(\mathrm{ng} / \mathrm{mL})$ of West African dwarf rams infected with $\mathrm{T}$. brucie brucei and $\mathrm{T}$. congolense for 70 days. 


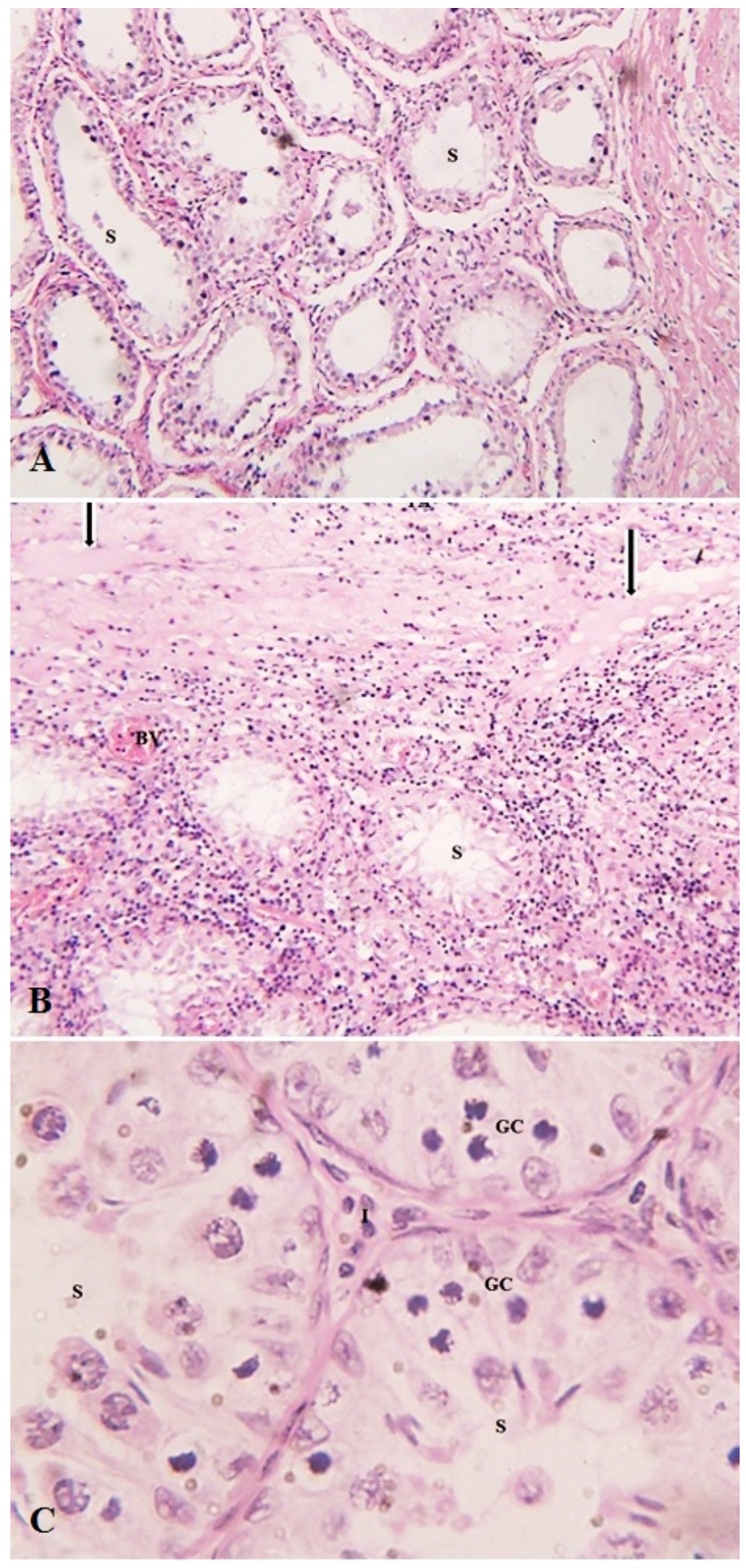

\section{Figure 9}

Testicular tissues of West African dwarf (WAD) rams infected with T. brucei brucei (A) and T. congolense (B) for 70 days, and that of the uninfected control (C). A: degeneration and necrosis of germ cells of the seminiferous tubules (S) with mild infiltration of mononuclear inflammatory cells in the interstices. B: severe degeneration and necrosis of germ cells of the seminiferous tubules $(S)$ with severe infiltration of mononuclear inflammatory cells in the interstices. Note the blood vessels (BV) and sub-capsular oedema 
(arrows). C: normal germs cells (GC) of the seminiferous tubules (S) and the interstitial cells of Leydig (I). H \& E stain (A \& B, x100; C x400).

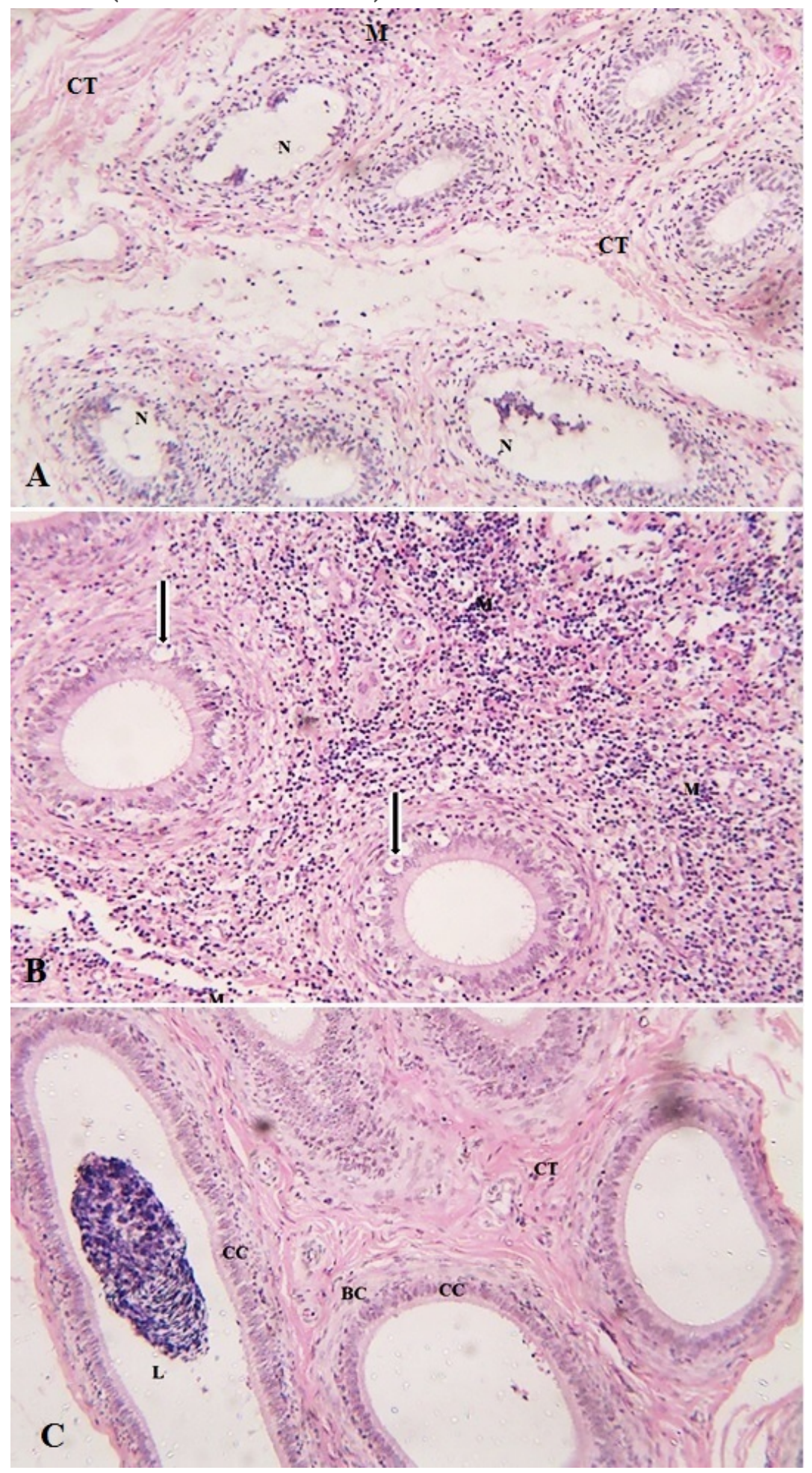

\section{Figure 10}

Epididymis of West African dwarf rams infected with T. brucei brucei (A) and T. congolense (B) for 70 days, and that of the uninfected control (C). A: severe necrosis (N) and desquamation of the tubular epithelial cells with moderate infiltration of mononuclear inflammatory cells (asterisk) in the connective tissues (CT). B: severe mononuclear cells infiltration (M) in the connective tissue and vacuolation at the base of the 
pseudostratified ciliated columnar epithelial cells of the tubules (arrows). C: normal epididymal tubules with clump of spermatozoa in the lumen (L). Note normal columnar cells $(\mathrm{CC})$ and basal cells (BC). H \& E Stain $\mathrm{x} 100$. 